\title{
Evaluation of Grafting Using Hybrid Rootstocks for Management of Bacterial Wilt in Field Tomato Production
}

\author{
Theodore McAvoy, Joshua H. Freeman, and Steven L. Rideout \\ Virginia Polytechnic Institute and State University, Eastern Shore \\ Agricultural Research and Extension Center, Painter, VA 23420 \\ Stephen M. Olson and Mathews L. Paret ${ }^{1}$ \\ University of Florida, North Florida Research and Education Center, 155 \\ Research Road, Quincy, FL 32351
}

Additional index words. Solanum lycopersicum, Ralstonia solanacearum, tube graft, bacterial disease management

\begin{abstract}
Seven hybrid tomato rootstocks with possible resistance to bacterial wilt caused by Ralstonia solanacearum and a known resistant cultivar were tested as grafting rootstocks to impart resistance to a bacterial wilt-susceptible cultivar, BHN 602 . Greenhouse studies showed resistance of all the rootstocks to bacterial wilt. The disease incidence and yield of 'BHN 602' grafted to these rootstocks were evaluated in open-field tomato production in Florida and Virginia over four seasons. Significant differences in bacterial wilt incidence were observed between grafted entries in three of the four trials. In these three trials, grafted entries consistently exhibited the least bacterial wilt incidence compared with the controls; the self-graft, and non-grafted entries. Over all the trials, tomato plants grafted onto 'Cheong Gang', 'BHN 1054', and 'BHN 998' displayed the least bacterial wilt incidence. Rootstocks had a significant effect on total marketable yield in all the trials with certain grafted entries yielding significantly greater than non-grafted 'BHN 602'. Field studies show that grafting holds promise for decreasing the impact of bacterial wilt on tomato cultivars as well as increasing the overall productivity of tomato cultivars.
\end{abstract}

Fresh-market tomato (Solanum lycopersicum) production is a vital part of the agricultural economy in Florida and Virginia. The fresh-market tomato industries in Florida and Virginia rank first and fourth nationally, respectively, and have a combined farm gate value of over $\$ 583$ million (USDA-NASS, 2011). Bacterial wilt of tomato caused by the soilborne bacterium Ralstonia solanacearum race 1 (biovar 1, phylotype II) is widely distributed in the southeastern United States and causes considerable economical losses under ideal conditions for disease incidence ( $\mathrm{Ji}$ et al., 2007). Once established, $R$. solanacearum can survive in the soil on the roots of asymptomatic plants, weeds, and plant debris (Elphinstone et al., 1998; Granada and Sequeira, 1983; Hayward, 1991). Although most soilborne pathogens have been traditionally managed with soil fumigants, this strategy has been

Received for publication 13 Jan. 2012. Accepted for publication 8 Mar. 2012.

This project was partially funded by a USDA methyl bromide transition grant.

We gratefully acknowledge East Coast Brokers and Packers for their support as well as Jackie Snell, Laura Ritchie, and the farm crew at NFREC, Quincy, for the technical support in conducting field trials.

${ }^{1}$ To whom reprint requests should be addressed; e-mail paret@ufl.edu. minimally effective against bacterial wilt (Chellemi et al., 1994; Enfinger et al., 1979). Crop rotation as a disease management strategy is effective but can be difficult because $R$. solanacearum can infect over 200 plant species (Hayward, 1994). Although resistance is available in tomato cultivars Hawaii 7996, Hawaii 7997, and Hawaii 7998 (Chellemi et al., 1994; Grimault and Prior, 1993; Grimault et al., 1995; Scott et al., 1989), these cultivars have not been widely accepted as a result of poor horticultural traits such as small fruit, a trait linked with bacterial wilt disease resistance (Opena et al., 1990; Wang et al., 1998).

Grafting has been practiced for decades in Asia as a technique to manage soilborne diseases and in 2003 grafted plants accounted for $81 \%$ and $54 \%$ of the vegetable acreage in Korea and Japan, respectively (Lee, 2003). Grafting has recently been gaining popularity in the United States, partly as a result of the loss of methyl bromide and the increased restrictions of using soil fumigants. Several studies have demonstrated the effectiveness of grafting to manage bacterial wilt in tomato but all have used open-pollinated breeding lines that are not widely available (Lin et al., 2008; Rivard and Louws, 2008). The level of bacterial wilt resistance in available hybrid lines is unknown. It is also unclear as to whether hybrid rootstocks would aid in increasing tomato fruit yield.
Previous research has indicated that resistance to bacterial wilt in tomato does not prevent the pathogen from entering the host root system but reduces its spread into the stem vasculature (Grimault and Prior, 1993; Prior et al., 1996). In the case of 'Hawaii 7996', a restriction in the movement of the pathogen from the protoxylem to other xylem tissues has been noted. As a result of this restriction, the incidence of bacterial wilt on a susceptible scion 'Ponderosa' grafted onto a 'Hawaii 7996' rootstock was significantly less compared with non-grafted and 'Ponderosa' grafted to a susceptible scion (Nakaho et al., 2004).

The objectives of this study were to 1) determine the level of bacterial wilt resistance present in new hybrid rootstocks with possible resistance to bacterial wilt; 2 ) assess the ability of the grafted plants in reducing bacterial wilt in tomato field production; and 3 ) determine the effect of the grafted plants on tomato fruit yield.

\section{Materials and Methods}

Greenhouse experiments. A wellcharacterized $R$. solanacearum race 1 strain Rs 5 (race 1, biovar 1, phylotype II) isolated from tomato in Quincy, FL (Ji et al., 2005, 2007) was streaked on a CPG agar plate and incubated at $28{ }^{\circ} \mathrm{C}$ for $48 \mathrm{~h}$. Pure mucoid colonies of the bacterial were suspended in sterile deionized water $\left(\mathrm{dH}_{2} \mathrm{O}\right)$ and adjusted spectrophotometrically to $\mathrm{OD}_{600 \mathrm{~nm}}=0.1$, which corresponds to $\approx 10^{8}$ colony-forming units $(\mathrm{CFU}) / \mathrm{mL}$. The $R$. solanacearum suspension was further diluted 10 -fold to adjust the bacterial population to $10^{7} \mathrm{CFU} / \mathrm{mL}$. Seventy-five milliliters of a bacterial suspension containing $10^{7} \mathrm{CFU} / \mathrm{mL}$ of $R$. solanacearum was poured into plastic pots filled with 750 $\mathrm{mL}$ of soilless potting medium (Sungro MetroMix 200 series; Sun Gro Horticulture Canada Ltd., British Columbia, Canada). The potting medium was evenly mixed with a sterile glass rod after inoculation. The rootstocks 'Jjak Kkung' (Seminis Vegetable Seeds, St. Louis, MO), 'Cheong Gang' (Seminis Vegetable Seeds), 'RST-04-105-T' (DP Seeds, Yuma, AZ), 'RST-04-106-T' (DP Seeds), 'Hawaii 7998' (public breeding material; University of Florida), 'BHN 998' (BHN Seed, Immokalee, FL), 'BHN 1053' (BHN Seed), 'BHN 1054' (BHN Seed), and the scion 'BHN 602' (BHN Seed) were transplanted into pots inoculated with $R$. solanacearum at the threeto four-leaf stage. The initial population of the bacterium in the potting medium was in the range of $10^{5}-10^{6} \mathrm{CFU} / \mathrm{g}$. The pots were arranged in a randomized complete block design. The temperature inside the greenhouse ranged between a minimum of $18-20{ }^{\circ} \mathrm{C}$ and maximum of $34-38^{\circ} \mathrm{C}$ throughout the duration of the experiments. Plants were irrigated daily with $100-150 \mathrm{~mL}$ of tap water to maintain a soil water capacity of $80 \%$ to $90 \%$. Plants were monitored for $28 \mathrm{~d}$ for bacterial wilt symptoms. Disease severity was scored on a scale of $0-4$ with $0=$ no symptoms, $1=$ one leaf with symptoms, 2 = two or three leaves wilted, 
$3=$ all except the top two or three leaves wilted, and $4=$ all leaves wilted or dead. Means were calculated by the formula [ $\sum$ (score $\times$ number of plants scored $) /($ total number of plants $\times$ highest score) $\times 100$ (Nakaho et al., 2004; Winstead and Kelman, 1952). Bacterial wilt was confirmed by plating of the extract from infected plant samples on semiselective modified SMSA medium (Engelbrecht, 1994) and also testing with Immunostrips (Agdia Inc., Elkhart, IN). Plants with no signs of wilting were also tested for the presence of latent infection by this method. The greenhouse experiments were conducted three times with seven plants per treatment in each trial.

Experimental treatments for field trials. In all trials, the tomato variety 'BHN 602' was used as a scion for grafted treatments as well as the non-grafted and self-grafted control. All trials included non-grafted and selfgrafted treatments. The 2009 trial in Virginia included two rootstocks; 'RST-04-105-T' and 'RST-04-106-T'. Resistance levels exhibited by 'RST-04-105-T' in the 2009 trial as well as in unreplicated field trials (J.H. Freeman, unpublished data) were poor and it was not included is subsequent field trials. The 2010 trial in Virginia included six rootstocks: 'RST-04-106-T', 'Cheong Gang', 'Jjak Kkung', 'BHN 998', 'BHN 1053', and 'BHN 1054'. The Spring 2010 trial in Florida included 'RST-04-106-T', 'Cheong Gang', 'Jjak Kkung', and 'Hawaii 7998'. The Fall 2010 Florida trial included 'RST-04-106-T', 'Cheong Gang', 'Jjak Kkung', 'BHN 998', 'BHN 1053', 'BHN 1054', and 'Hawaii 7998'.

Transplant production and grafting for field trials. Seedlings were grafted using a modified Japanese tube graft at the two-leaf stage (Rivard and Louws, 2006). Recent research has indicated that grafting in this manner resulted in rootstock regrowth (Bausher, 2011). As a result of the vigor of the rootstocks used, this type of growth would necessitate pruning on a biweekly basis, which would be unsuitable for commercial field production. Thus, all grafted treatments were grafted below the rootstock cotyledons to prevent rootstock regrowth. Seedlings were grown pre- and postgrafting in expanded polystyrene trays of the inverted pyramid design with cell size $4.4 \times$ $4.4 \times 6.3 \mathrm{~cm}$. Soilless media was used for the production of all transplants. After grafting was performed, seedlings were placed in a high-humidity chamber with controlled temperature to heal the graft union (Rivard and Louws, 2006). After 1 week, seedlings were removed from the chamber and placed in a greenhouse for 10-14 d until transplanting. As a result of grafting below the rootstock cotyledon, care was taken at planting to maintain the graft union above the soil line.

Field experiments. Four field trials were conducted in Florida and Virginia during 2009 and 2010. Two of these trials were conducted on a commercial tomato farm in Painter, VA, during the spring of 2009 and 2010. Soil type was Bojac sandy loam with $\mathrm{pH}$ 6.2. Two trials were conducted at the University of Florida North Florida Research and Education Center in Quincy, FL, during the spring and fall of 2010 . Soil type was Norfolk sandy loam with $\mathrm{pH}$ 6.3. Experimental plots at both locations consisted of nonfumigated raised beds covered with black polyethylene mulch for spring plantings and white polyethylene mulch for fall plantings. Bed dimensions at Virginia were $20.3 \mathrm{~cm}$ tall $\times 76.2 \mathrm{~cm}$ wide. Beds were spaced $1.8 \mathrm{~m}$ apart and plants were spaced $45.7 \mathrm{~cm}$ within the row. Bed dimensions at Florida were 12.7 $\mathrm{cm}$ tall $\times 76.2 \mathrm{~cm}$ wide. Beds were spaced 1.8 $\mathrm{m}$ apart and plants were spaced $50.8 \mathrm{~cm}$ within the row. Inorganic fertilizers were applied to experimental plots based on soil test results and cooperative extension recommendations for respective states (Kuhar et al., 2011; Olson et al., 2011). The Virginia field plots had a history of bacterial wilt and were not inoculated. The Florida field plots did not have a history of bacterial wilt. To ensure disease development in the Florida field trial, experimental plots were inoculated with $R$. solanacearum Rs 5 strain. The strain was cultured by the methods described previously. Seventyfive milliliters of an aqueous solution containing $10^{7} \mathrm{CFU} / \mathrm{mL}$ of $R$. solanacearum was poured in each plant hole $1 \mathrm{~d}$ before transplanting. This created an initial bacterial population in the range of $10^{5}-10^{6} \mathrm{CFU} / \mathrm{g}$ of soil. Grafted seedlings were transplanted on 29 May 2009 and 30 Apr. 2010 in Virginia and 20 Apr. 2010 and 11 Aug. 2010 in Florida. Each entry in the Virginia and Florida trials consisted of four replications with 30 and 18 plants, respectively, in each replication. All experiments were arranged as a randomized complete block design. The bacterial wilt incidence was calculated at weekly intervals as the percentage of plants that had completely wilted. However, only the final data at the harvesting are presented in the results because that represents a direct correlation with the total yield. The cause of the wilting was confirmed using $R$. solanacearum-specific immunostrips. Disease incidence data are presented as percent incidence as recorded just after the final harvest. Experimental plots were maintained throughout the season with standard crop protection practices for commercial tomato production (Kuhar et al., 2011; Olson et al., 2011). Twelve plants from the center of each plot were marked independent of their disease status, and fruits were harvested from these plants at a mature green/early breaker stage and graded by USDA grades (USDA, 1976). Two to three harvests were made for each trial, which is typical of commercial tomato production in both states.

Statistical analysis. The greenhouse studies and field studies were set up in a randomized complete block design. The data were analyzed using analysis of variance, and the means were compared using least significant difference. The analysis was performed with SAS (SAS Version 9.1; SAS Institute Inc., Cary, NC).

\section{Results}

Greenhouse experiments. All the rootstocks showed significant reduction in bacterial wilt incidence as indicated by the percentage of plants wilted and the disease severity compared with the susceptible scion 'BHN 602' (Table 1). Among the rootstocks, 'RST-04105-T' exhibited higher disease incidence

Table 1. Resistance of tomato rootstocks ('Jjak Kkung', 'Cheong Gang', 'RST-04-105-T, 'RST-04-106T', 'Hawaii 7998', 'BHN 998', 'BHN 1053', 'BHN 1054') and scion ('BHN 602') to the bacterial wilt strain Rs 5 isolated from tomato in Quincy, FL. ${ }^{z}$

\begin{tabular}{|c|c|c|c|c|}
\hline \multirow[b]{2}{*}{ Entry } & \multicolumn{3}{|c|}{ Percentage plants ${ }^{\mathrm{y}}(\%)$} & \multirow{2}{*}{$\begin{array}{c}\text { Disease } \\
\text { severity index }\end{array}$} \\
\hline & Wilted & Latently infected $^{\mathrm{v}}$ & Healthy $^{\mathrm{u}}$ & \\
\hline Jjak Kkung & $19.05 \mathrm{c}^{\mathrm{w}}$ & $38.10 \mathrm{a}$ & $42.86 \mathrm{ab}$ & $14.88 \mathrm{~cd}$ \\
\hline Cheong Gang & $14.29 \mathrm{c}$ & $33.33 \mathrm{ab}$ & $52.38 \mathrm{a}$ & $10.27 \mathrm{~cd}$ \\
\hline RST-04-105-T & $47.62 \mathrm{~b}$ & $28.57 \mathrm{ab}$ & $23.81 \mathrm{bc}$ & $45.24 \mathrm{~b}$ \\
\hline RST-04-106-T & $19.05 \mathrm{c}$ & $28.57 \mathrm{ab}$ & $52.38 \mathrm{a}$ & $17.86 \mathrm{~cd}$ \\
\hline Hawaii 7998 & $9.52 \mathrm{c}$ & $28.57 \mathrm{ab}$ & $61.90 \mathrm{a}$ & $7.14 \mathrm{~d}$ \\
\hline BHN 998 & $19.05 \mathrm{c}$ & $19.05 \mathrm{bc}$ & $61.90 \mathrm{a}$ & $16.67 \mathrm{~cd}$ \\
\hline BHN 1053 & $28.57 \mathrm{bc}$ & $28.57 \mathrm{ab}$ & $42.86 \mathrm{ab}$ & $26.19 \mathrm{c}$ \\
\hline BHN 1054 & $23.81 \mathrm{c}$ & $33.33 \mathrm{ab}$ & $42.86 \mathrm{ab}$ & $20.24 \mathrm{~cd}$ \\
\hline BHN 602 & $85.71 \mathrm{a}$ & $4.76 \mathrm{c}$ & $9.52 \mathrm{c}$ & $80.95 \mathrm{a}$ \\
\hline $\begin{array}{l}\text { Least significant } \\
\text { difference }(0.05)\end{array}$ & 20.00 & 17.65 & 21.61 & 17.24 \\
\hline$P>F$ & $<0.0001$ & 0.0365 & 0.0012 & $<0.0001$ \\
\hline
\end{tabular}

zPlants at the three- to four-leaf stage were transplanted into pots inoculated with the $R$. solanacearum strain. The initial population of the bacterial pathogen was in the range of $10^{5}-10^{6}$ colony-forming units/ gram of potting medium. The percentage of plants wilted, latently infected, and healthy, and the disease severity index are given.

${ }^{\mathrm{y}} \mathrm{A}$ total of 21 plants were tested (seven plants per rootstock/scion in a experiment and the experiments were conducted three times).

${ }^{\mathrm{x}}$ Disease severity index was scored at $28 \mathrm{~d}$ after inoculation on a scale of $0-4$ with $0=$ no symptoms, $1=$ one leaf with symptoms, 2 = two or three leaves wilted, 3 = all except the top two or three leaves wilted, and $4=$ all leaves wilted or dead and calculated by the formula $\left[\sum\right.$ (score $\times$ number of plants scored)/(total number of plants $\times$ highest score) $] \times 100$ (Nakaho et al., 2004; Winstead and Kelman, 1952).

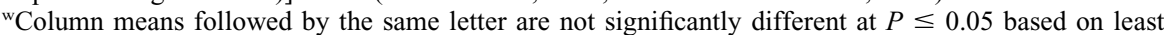
significant difference.

'Latently infected represents the percentage of plants that were non-symptomatic but had $R$. solanacearum recovered from the stem.

${ }^{u}$ Healthy represents the percentage of plants that were non-symptomatic, and $R$. solanacearum was not recovered from the stem. 
and disease severity than other rootstocks. 'Hawaii 7998' and 'Cheong Gang' were the most resistant rootstocks in the greenhouse studies. All rootstocks except 'BHN 998' had significantly higher latently infected plants than 'BHN 602'. The percentages of healthy plants (no symptoms and no latent infection) were significantly lower in 'BHN 602' compared with all the rootstocks except 'RST-04105-T'. Among the rootstocks, 'BHN 998', 'Hawaii 7998', 'Cheong Gang', and 'RST04-106-T' had the highest percentage of healthy plants.

Field experiments. Rootstock had a significant effect on bacterial wilt incidence in three experiments and tomato fruit yield in all experiments (Tables 2-5). The greatest yield and least disease incidence were always observed in one of the grafted treatments on a resistant rootstock.

Virginia 2009. Disease incidence was low to moderate in this trial. Rootstock treatment did not have a significant effect on disease incidence and no non-grafted plants exhibited bacterial wilt symptoms. The entry with the greatest numerical disease incidence was the self-grafted followed by 'RST-04-105-T' and 'RST-04-106-T' (Table 2). Despite disease development in the non-grafted treatment, plants grafted onto 'RST-04-106-T' produced significantly greater total marketable yields than other treatments (Table 2). There were no differences in fruit yield between the remaining treatments.

Virginia, 2010. Disease incidence was severe in this trial and rootstock treatment had a significant effect on percent incidence as well as fruit yield in all size categories and total marketable. All rootstock treatments yielded significantly greater than the nongrafted and self-grafted treatments (Table 3). Plants grafted onto 'Jjak Kkung' yielded $50,123 \mathrm{~kg} \cdot \mathrm{ha}^{-1}$ of marketable fruit, which was significantly less than plants grafted onto 'RST-4-106-T', 'Cheong Gang', 'BHN 1054', and 'BHN 998'. Plants grafted onto 'BHN 1053 ' yielded similarly to all other rootstock treatments with respect to marketable yield. No yield data were obtained from the selfgrafted treatment as a result of near complete mortality at harvest. Least disease incidence was exhibited in rootstock treatments 'BHN 1054', 'Cheong Gang', 'BHN 998', and 'RST04-106-T'. These treatments all exhibited 13\% or less disease incidence at harvest. Disease incidence in these treatments was significantly less than all other treatments. An intermediate level of disease incidence was observed in plants grafted onto 'BHN 1053' at 43.5\%. Disease incidence exhibited by self-grafted plants was $97 \%$, which was similar to non-grafted plants and plants grafted to 'Jjak Kkung'. However 'Jjak Kkung' had significantly higher yield compared with non-grafted and selfgrafted entries.

Florida, Spring 2010. Although bacterial wilt incidence was low overall $(7.5 \%$ incidence or less) in this trial, rootstock treatment significantly affected disease incidence and tomato fruit yield. Numerically, greatest fruit yield was obtained from plants grafted onto

Table 2. Bacterial wilt incidence and yield of 'BHN 602' non-grafted or grafted onto rootstocks for bacterial wilt resistance in a field naturally infested with $R$. solanacearum in Painter, VA. ${ }^{ }$

\begin{tabular}{|c|c|c|c|c|c|}
\hline \multirow[b]{2}{*}{ Entry ${ }^{y}$} & \multicolumn{4}{|c|}{ Fruit yield $\left(\mathrm{kg} \cdot \mathrm{ha}^{-1}\right)$} & \multirow{2}{*}{$\begin{array}{l}\text { Bacterial wilt } \\
\text { incidence }(\%)^{\mathrm{x}}\end{array}$} \\
\hline & Medium & Large & Extra large & Total marketable & \\
\hline Non-grafted & 4,370 & 18,004 & $40,236 a^{w}$ & $62,610 \mathrm{~b}$ & 0.0 \\
\hline RST-04-106-T & 5,556 & 22,034 & $48,027 \mathrm{a}$ & $75,619 \mathrm{a}$ & 1.5 \\
\hline RST-04-105-T & 7,783 & 20,930 & $26,508 \mathrm{~b}$ & $55,312 \mathrm{~b}$ & 11.2 \\
\hline Self-grafted & 4,107 & 16,689 & $39,768 \mathrm{ab}$ & $60,564 \mathrm{~b}$ & 18.2 \\
\hline $\begin{array}{l}\text { Least significant } \\
\text { difference }(0.05)\end{array}$ & NS & NS & 13,849 & 12,276 & NS \\
\hline$P>F$ & 0.2128 & 0.4465 & 0.0396 & 0.0253 & 0.1133 \\
\hline
\end{tabular}

${ }^{\mathrm{z}}$ The experiment was conducted in Spring 2009.

${ }^{y}$ Each entry consisted of four replications with 30 plants in each replication, and the experiment was arranged as a randomized complete block design.

xPercentage bacterial wilt incidence at the time of harvest.

${ }^{\text {w}}$ Column means followed by the same letter are not significantly different at $P \leq 0.05$ based on least significant difference.

NS $=$ nonsignificant

Table 3. Bacterial wilt incidence and yield of 'BHN 602' non-grafted or grafted onto rootstocks for bacterial wilt resistance in a field naturally infested with $R$. solanacearum in Painter, VA. ${ }^{\mathrm{z}}$

\begin{tabular}{|c|c|c|c|c|c|}
\hline \multirow[b]{2}{*}{ Entry ${ }^{y}$} & \multicolumn{4}{|c|}{ Fruit yield $\left(\mathrm{kg} \cdot \mathrm{ha}^{-1}\right)$} & \multirow[b]{2}{*}{$\begin{array}{l}\text { Bacterial wilt } \\
\text { incidence }(\%)^{x}\end{array}$} \\
\hline & Medium & Large & Extra large & $\begin{array}{c}\text { Total } \\
\text { marketable }\end{array}$ & \\
\hline$\overline{B H N} 1054$ & $5,420 \mathrm{a}^{\mathrm{w}}$ & $16,371 \mathrm{ab}$ & $58,158 \mathrm{ab}$ & $79,950 \mathrm{a}$ & $5.0 \mathrm{c}$ \\
\hline Cheong Gang & $4,113 \mathrm{ab}$ & $14,211 \mathrm{bc}$ & $60,605 \mathrm{a}$ & $78,928 \mathrm{a}$ & $6.5 \mathrm{c}$ \\
\hline BHN 998 & $4,648 \mathrm{a}$ & $14,013 \mathrm{bc}$ & $55,645 \mathrm{ab}$ & $74,306 \mathrm{a}$ & $10.5 \mathrm{c}$ \\
\hline RST-04-106-T & $5,136 \mathrm{a}$ & $19,176 \mathrm{a}$ & $56,139 \mathrm{ab}$ & 80,451 a & $13.0 \mathrm{c}$ \\
\hline BHN 1053 & $2,459 \mathrm{~b}$ & $9,852 \mathrm{c}$ & $46,551 \mathrm{ab}$ & $58,863 \mathrm{ab}$ & $43.5 \mathrm{~b}$ \\
\hline Jjak Kkung & $4,357 \mathrm{a}$ & $9,954 \mathrm{c}$ & $35,813 \mathrm{~b}$ & $50,123 \mathrm{~b}$ & $56.0 \mathrm{ab}$ \\
\hline Non-grafted & $474 \mathrm{c}$ & $1,938 \mathrm{~d}$ & $13,959 \mathrm{c}$ & $16,371 \mathrm{c}$ & $85.5 \mathrm{ab}$ \\
\hline Self-grafted & $0 \mathrm{c}$ & $0 \mathrm{~d}$ & $0 \mathrm{c}$ & $0 \mathrm{c}$ & $97.0 \mathrm{a}$ \\
\hline $\begin{array}{l}\text { Least significant } \\
\text { difference }(0.05)\end{array}$ & 1,855 & 4,390 & 20,705 & 24,075 & 21.1 \\
\hline$P>F$ & $<0.0001$ & $<0.0001$ & $<0.0001$ & $<0.0001$ & $<0.0001$ \\
\hline
\end{tabular}

${ }^{2}$ The experiment was conducted in Spring 2010.

${ }^{y}$ Each entry consisted of four replications with 30 plants in each replication, and the experiment was arranged as a randomized complete block design.

${ }^{x}$ Percentage bacterial wilt incidence at the time of harvest.

${ }^{\text {w}}$ Column means followed by the same letter are not significantly different at $P \leq 0.05$ based on least significant difference.

NS = nonsignificant.

'RST-04-106-T' followed by 'Cheong Gang' and 'Jjak Kkung' (Table 4). All rootstock treatments resulted in significantly less bacterial wilt incidence compared with the non-grafted and self-grafted treatments. The self-grafted treatment exhibited significantly less bacterial wilt incidence than the nongrafted treatment.

Florida, Fall 2010. Bacterial wilt incidence was severe in this trial and rootstock treatment had a significant effect on disease incidence as well as tomato fruit yield. Nongrafted and self-grafted treatments exhibited the greatest amount of bacterial wilt incidence, $93.8 \%$ and $93.9 \%$, respectively (Table 5). Plants grafted onto 'BHN 1053' exhibited similar amounts of disease incidence. Rootstock treatment 'Cheong Gang' resulted in the lowest disease incidence $(28.4 \%)$ but was statistically similar to 'BHN 998', and 'BHN 1054'. 'Hawaii 7998', 'RST04-106-T', and 'Jjak Kkung' had significantly higher disease incidence than 'Cheong Gang' but significantly less than the non-grafted and self-grafted treatments. The non-grafted and self-grafted treatments produced less than $400 \mathrm{~kg} \cdot \mathrm{ha}^{-1}$ of tomato fruit but were statistically similar to all treatments but 'BHN 1054' 'BHN 998', and 'Cheong Gang' at 47,728 $\mathrm{kg} \cdot \mathrm{ha}^{-1}, 30,194$ $\mathrm{kg} \cdot \mathrm{ha}^{-1}$, and 28,733 $\mathrm{kg} \cdot \mathrm{ha}^{-1}$, respectively.

\section{Discussion}

Tomato producers in the United States face losses in productivity as a result of soilborne pests. For decades these pests have been managed with soil fumigants, primarily methyl bromide. The use of methyl bromide is nearly finished in the United States as a result of its phase-out under the Montreal Protocol (EPA, 2011; Rosskopf et al., 2005; UNEP, 2011). Even with the use of soil fumigants, management of some pathogens such as bacterial wilt caused by $R$. solanacearum can be limited (Chellemi et al., 1997; Enfinger et al., 1979). Producers are currently seeking alternatives to soil fumigation to manage soilborne pests in tomato. Grafting with resistant rootstocks may provide growers with a sustainable and eco-friendly practice for bacterial wilt management (Rivard and Louws, 2008). The current study is unique because it is the first study in the United States that included numerous new hybrid rootstocks available to 
Table 4. Bacterial wilt incidence and yield of 'BHN 602' non-grafted or grafted onto rootstocks for bacterial wilt resistance in a field artificially inoculated with $R$. solanacearum in Quincy, FL. ${ }^{z}$

\begin{tabular}{|c|c|c|c|c|c|}
\hline \multirow[b]{2}{*}{ Entry ${ }^{y}$} & \multicolumn{4}{|c|}{ Fruit yield $\left(\mathrm{kg} \cdot \mathrm{ha}^{-1}\right)$} & \multirow[b]{2}{*}{$\begin{array}{l}\text { Bacterial wilt } \\
\text { incidence }(\%)^{x}\end{array}$} \\
\hline & Medium & Large & Extra large & $\begin{array}{c}\text { Total } \\
\text { marketable }\end{array}$ & \\
\hline$\overline{R S T-04-106-T}$ & 4,022 & $10,065 \mathrm{~b}^{\mathrm{w}}$ & 40,840 & $54,927 \mathrm{a}$ & $0.0 \mathrm{c}$ \\
\hline Cheong Gang & 4,171 & $11,895 \mathrm{a}$ & 36,129 & $52,195 \mathrm{a}$ & $0.0 \mathrm{c}$ \\
\hline Jjak Kkung & 4,575 & $10,170 \mathrm{ab}$ & 36,049 & $50,794 \mathrm{a}$ & $0.0 \mathrm{c}$ \\
\hline Hawaii 7998 & 6,019 & $9,682 \mathrm{bc}$ & 30,164 & $45,865 \mathrm{ab}$ & $0.0 \mathrm{c}$ \\
\hline Self-grafted & 5,162 & $8,179 \mathrm{~b}$ & 33,532 & $46,874 \mathrm{ab}$ & $2.7 \mathrm{~b}$ \\
\hline Non-grafted & 3,589 & $8,567 \mathrm{bc}$ & 28,263 & $40,419 \mathrm{~b}$ & $7.5 \mathrm{a}$ \\
\hline $\begin{array}{l}\text { Least significant } \\
\text { difference }(0.05)\end{array}$ & NS & 1,728 & NS & 9,059 & 2.4 \\
\hline$P>F$ & 0.1147 & 0.0041 & 0.1160 & 0.0428 & $<0.0001$ \\
\hline
\end{tabular}

${ }^{\mathrm{z}}$ The experiment was conducted in Spring 2010.

${ }^{\mathrm{y}}$ Each entry consisted of four replications with 18 plants in each replication, and the experiment was arranged as a randomized complete block design.

${ }^{x}$ Percentage bacterial wilt incidence at the time of harvest.

${ }^{\text {w}}$ Column means followed by the same letter are not significantly different at $P \leq 0.05$ based on least significant difference.

NS $=$ nonsignificant

Table 5. Bacterial wilt incidence and yield of 'BHN 602' non-grafted or grafted onto rootstocks for bacterial wilt resistance in a field artificially inoculated with $R$. solanacearum in Quincy, FL. ${ }^{2}$

\begin{tabular}{lccccc}
\hline & \multicolumn{4}{c}{ Fruit yield $\left(\mathrm{kg} \cdot \mathrm{ha}^{-1}\right)$} & \\
\cline { 2 - 4 } Entry & Medium & Large & Extra large & $\begin{array}{c}\text { Total } \\
\text { marketable }\end{array}$ & $\begin{array}{c}\text { Bacterial wilt } \\
\text { incidence }(\%)^{\mathrm{x}}\end{array}$ \\
\hline Cheong Gang & $3,026 \mathrm{ab}^{\mathrm{w}}$ & $7,455 \mathrm{ab}$ & $18,293 \mathrm{abc}$ & $28,733 \mathrm{ab}$ & $28.4 \mathrm{~d}$ \\
BHN 998 & $2,663 \mathrm{ab}$ & $5,661 \mathrm{~b}$ & $21,870 \mathrm{ab}$ & $30,194 \mathrm{ab}$ & $40.0 \mathrm{~cd}$ \\
BHN 1054 & $3,929 \mathrm{a}$ & $11,313 \mathrm{a}$ & $32,486 \mathrm{a}$ & $47,728 \mathrm{a}$ & $40.6 \mathrm{~cd}$ \\
Hawaii 7998 & $1,311 \mathrm{bc}$ & $2,877 \mathrm{bc}$ & $7,595 \mathrm{bc}$ & $11,784 \mathrm{bc}$ & $53.6 \mathrm{bc}$ \\
RST-04-106-T & $1,320 \mathrm{bc}$ & $2,916 \mathrm{bc}$ & $7,160 \mathrm{bc}$ & $11,395 \mathrm{bc}$ & $57.8 \mathrm{bc}$ \\
Jjak Kkung & $1,385 \mathrm{bc}$ & $2,264 \mathrm{bc}$ & $3,785 \mathrm{bc}$ & $7,434 \mathrm{bc}$ & $67.9 \mathrm{~b}$ \\
BHN 1053 & $1,505 \mathrm{bc}$ & $3,060 \mathrm{bc}$ & $10,494 \mathrm{~b}$ & $15,059 \mathrm{bc}$ & $76.1 \mathrm{ab}$ \\
Non-grafted & $102 \mathrm{c}$ & $75 \mathrm{c}$ & $199 \mathrm{c}$ & $376 \mathrm{c}$ & $93.8 \mathrm{a}$ \\
Self-grafted & $43 \mathrm{c}$ & $73 \mathrm{c}$ & $117 \mathrm{c}$ & $232 \mathrm{c}$ & $93.9 \mathrm{a}$ \\
& & & & & \\
Least significant & 2,142 & 5,374 & 19,096 & 25,914 & 24.7 \\
$\quad$ difference (0.05) & & & & & \\
$P>F$ & 0.0136 & 0.0040 & 0.0241 & 0.0132 & $<0.0001$ \\
\hline
\end{tabular}

${ }^{\mathrm{z}}$ The experiment was conducted in Fall 2010.

${ }^{\mathrm{y}}$ Each entry consisted of four replications with 18 plants in each replication, and the experiment was arranged as a randomized complete block design.

${ }^{x}$ Percentage bacterial wilt incidence at the time of harvest.

${ }^{\text {w }}$ Column means followed by the same letter are not significantly different at $P \leq 0.05$ based on least significant difference.

growers and evaluated in two geographic locations for resistance to bacterial wilt of tomato.

The use of rootstocks with resistance to bacterial wilt had a significant effect on tomato fruit yield and bacterial wilt incidence in nearly all experiments during 2009 and 2010. In two instances, bacterial wilt disease pressure was low yet rootstock still had a significant effect on marketable tomato fruit yield. In the trials in which disease pressure was severe, rootstock treatments significantly reduced disease symptom expression and maintained an acceptable fruit yield. There was disparity between the results obtained in Virginia in 2010 and Florida in the Fall of 2010. Disease was severe in both instances, non-grafted and self-grafted controls exhibiting greater than $85 \%$ disease incidence, but symptom expression varied by location. In Virginia, rootstocks exhibited less disease than in Florida. Representative $R$. solanacearum strains from both locations were typed and found to be biovar 1, phylotype II, sequevar 7 (Ji et al., reduce the cost of moving production from location to location.

A recent study used two open-pollinated tomato-breeding lines, 'CRA 66' and 'Hawaii 7996', as rootstocks for field production of heirloom tomatoes and reported no disease incidence in plants grafted to either rootstock, whereas non-grafted and self-grafted entries exhibited $50 \%$ to $80 \%$ incidence (Rivard and Louws, 2008). A similar rootstock, 'Hawaii 7998', was used in both Florida trials and exhibited $53.6 \%$ disease incidence when disease pressure was high. In Virginia in 2010, disease incidence was high and the most resistant rootstock exhibited 5\% incidence and was statistically similar to rootstocks that exhibited $13 \%$ incidence. Differential resistance of various bacterial wilt-resistant breeding lines to $R$. solanacearum strains have been previously studied, which indicated that 'Hawaii 7996' and 'Hawaii 7998' were the two most stable resistant lines tested (Lin et al., 2008). However, these lines were not completely resistant to all strains with which they were challenged. This may explain the disparity between the results presented by Rivard and Louws (2008) and the results presented here.

There was some indication from the Florida experiments that there may be a yield advantage to using hybrid rootstocks. In the spring when disease pressure was low, several entries grafted to hybrid rootstocks produced fruit yield that was numerically but not significantly greater than plants grafted to 'Hawaii 7998'. This trend was more evident in the fall when plants grafted to 'Hawaii 7998' yielded significantly less than plants grafted to 'BHN 1054', whereas disease incidence was similar. Fruit yield from plants grafted to 'Hawaii 7998' was statistically similar to all other hybrid rootstock entries but produced much lower fruit yield than plants grafted to 'BHN 998' and 'Cheong Gang'. This may be the result of complex factors such as bacterial populations within the stem or it may be the result of rootstock vigor. In 2009, plants grafted to 'RST-04106 - $T$ ' yielded significantly greater than nongrafted 'BHN 602', which was exhibiting no disease symptoms. In similar experiments conducted in North Carolina, marketable yields of 'German Johnson' grafted onto 'Hawaii 7996' and 'CRA 66' were less than 22,000 kg.ha' (Rivard and Louws, 2008). Although a different scion was used in the current experiments, tomato fruit yield was much greater. In addition, experiments comparing non-grafted and self-grafted 'German Johnson' to 'German Johnson' grafted onto hybrid rootstocks 'Maxifort' and 'Robusta' had greater marketable fruit yields of up to $65,000 \mathrm{~kg} \cdot \mathrm{ha}^{-1}$ but no significant difference among the non-grafted, self-grafted, and hybrid rootstock entries (Rivard and Louws, 2008). The effect of hybrid vs. open-pollinated rootstocks on tomato fruit yield remains questionable but is an area that needs further investigation. Another area with very little information is the effect of grafted plants with resistant rootstocks on the long-term 
populations of $R$. solanacearum in the soil. Our research group's preliminary greenhouse studies have indicated that there was no significant drop in the pathogen population in the potting medium of healthy and latently infected rootstocks from initial inoculum levels during the 28 -d period of the experiment (M.L. Paret, unpublished data). Further field studies are in progress to examine long-term effects of grafting on $R$. solanacearum populations.

One of the restrictions in commercialization of grafting for open-field tomato production right now is the lack of major suppliers of grafted tomatoes at affordable costs. A recent economic analysis (Rivard et al., 2010) has determined that costs of a single grafted plant and non-grafted plant were at \$0.59 and \$0.13 in North Carolina and \$1.29 and \$ 0.51 in Pennsylvania, respectively. In Florida, greenhouse tomato growers have been purchasing grafted plants from Canada costing approximately $\$ 1.00$ 1.75 per grafted plant (Emil Belibasis, Beli Farms, Wellborn, FL; personal communication). Although grafting requires higher initial investment on the costs of transplants, it significantly reduces disease incidence and provides a significant increase in marketable yield as indicated in our current study. This could offset any additional expenses that growers may have to spend for purchasing/ producing grafted plants. Grafted plants also performed very well in non-fumigated soil. Elimination of the cost of soil fumigation could also make the use of grafted plants more economically feasible.

These studies illustrate the benefits of grafting susceptible tomato scions onto resistant hybrid rootstocks when planted into soils heavily infested with $R$. solanacearum. Disease incidence was greatly reduced and tomato fruit yield was maintained at levels acceptable to commercial producers. These data indicate that several commercially available hybrid rootstocks have high levels of bacterial wilt resistance. 'Cheong Gang', 'BHN 1054', and 'BHN 998' were the most adapted rootstocks with respect to bacterial wilt resistance and resulting tomato fruit yield.

\section{Literature Cited}

Bausher, M. 2011. Grafting technique to eliminate rootstock suckering of grafted tomatoes. HortScience 46:596-598.

Chellemi, D.O., S.M. Olson, D.J. Mitchell, I. Secker, and R. McSorley. 1997. Adaptation of soil solarization to the integrated management of soilborne pests of tomato under humid conditions. Phytopathology 87:250-258.

Chellemi, D.O., S.M. Olson, and J.W. Scott. 1994 Field evaluation of tomato genotypes for resistance to bacterial wilt. Proc. Fla. State Hort. Soc. 107:151-153.

Elphinstone, J.G., J.K. Hennessy, and D.E. Stead. 1998. Detection of Ralstonia solanacearum in potato tubers, Solanum dulcamara and associated irrigation water, p. 133-139. In: Prior, P. C. Allen, and J. Elphinstone (eds.). Bacterial wilt disease: Molecular and ecological aspects. Springer-Verlag, Berlin, Germany.

Enfinger, J.M., S.M. McCarter, and C.A. Jaworski. 1979. Evaluation of chemicals and application methods for control of bacterial wilt of tomato transplants. Phytopathology 69:637-640.

Engelbrecht, M.C. 1994. Modification of a semiselective medium for the isolation and quantification of Pseudomonas solanacearum. ACIAR Bacterial Wilt Newsletter. 10:3-5.

EPA. 2011. The phaseout of methyl bromide. 22 Apr. 2011. <http://www.epa.gov/ozone/mbr/>

Granada, G.A. and L. Sequeira. 1983. Survival of Pseudomonas solanacearum in soil, rhizosphere, and plant roots. Can. J. Microbiol. 29: 433-440.

Grimault, V., P. Prior, and G. Anais. 1995. A monogenic dominant resistance of tomato to bacterial wilt in Hawaii 7996 is associated with plant colonization by Pseudomonas solanacearum. J. Phytopathol. 143:349-352.

Grimault, V. and P. Prior. 1993. Bacterial wilt resistance in tomato associated with tolerance of vascular tissues to Pseudomonas solanacearum. Plant Pathol. 42:589-594.

Hayward, A.C. 1991. Biology and epidemiology of bacterial wilt caused by Pseudomonas solanacearum. Annu. Rev. Phytopathol. 29:65-87.

Hayward, A.C. 1994. The hosts of Pseudomonas solanacearum, p. 9-24. In: Hayward, A.C. and G.L. Hartman (eds.). Bacterial wilt: The disease and its causative agent, Pseudomonas solanacearum. CAB International, Wallington, UK.

Ji, P., C. Allen, A. Sanchez-Perez, J. Yao, J.G. Elphinstone, J.B. Jones, and M.T. Momol. 2007. New diversity of Ralstonia solanacearum strains associated with vegetable and ornamental crops in Florida. Plant Dis. 91:195-203.

Ji, P., M.T. Momol, S.M. Olson, P.M. Pradhanang, and J.B. Jones. 2005. Evaluation of thymol as biofumigant for control of bacterial wilt of tomato under field conditions. Plant Dis. 89:497-500.

Kuhar, T.P., C. Waldenmaier, H.B. Doughty, S. Rideout, J.H. Freeman, M. Reiter, R.A. Straw, H.P. Wilson, and T.E. Hines. 2011. Commercial vegetable production recommendations. Virginia Coop. Ext. Pub. 456-420.

Lee, J.M. 2003. Advances in vegetable grafting. Chron. Horticult. 43:13-19.

Lin, C.-H., S.-T. Hsu, K.-C. Tzeng, and J.-F. Wang. 2008. Application of a preliminary screen to select locally adapted resistant rootstock and soil amendment for integrated management of tomato bacterial wilt in Taiwan. Plant Dis. 92:909-916.

Nakaho, K., H. Inoue, T. Takayama, and H. Miyagawa. 2004. Distribution and multiplication of Ralstonia solanacearum in tomato plants with resistance derived from different origins. J. Gen. Plant Pathol. 70:115-119.

Olson, S.M., G.E. Stall, S.E. Vallad, S.E. Webb, S.A. Smith, E.H. Simonne, E.J. McAvoy, B.M. Santos, and M. Ozores-Hampton. 2011. Tomato production in Florida, p. 297-308. In: Olson, S.M. and B.M. Santos (eds.). Vegetable production handbook of Florida. Vance Publishing Corporation, Lenexa, KS.

Opena, R.T., G.L. Hartman, J.T. Chen, and C.H. Yang. 1990. Breeding for bacterial wilt resistance in tropical tomato. Proc. Int. Conf. Plant Prot. Trop. 3rd. Genting Highlands, Pahang, Malaysia. p. 44-50.

Prior, P., S. Bart, S. Leclercq, A. Darasse, and G. Anais. 1996. Resistance to bacterial wilt in tomato as discerned by spread of Pseudomonas (Burkholderia) solanacearum in the stem tissues. Plant Pathol. 45:720-726.

Rivard, C.L. and F.J. Louws. 2006. Grafting for disease resistance in heirloom tomatoes. North Carolina Coop. Ext. Serv. Bul. Ag-675.

Rivard, C.L. and F.J. Louws. 2008. Grafting to manage soilborne diseases in heirloom tomato production. HortScience 43:2104-2111.

Rivard, C.L., O. Sydorovych, S. O’Connell, M.M. Peet, and F.J. Louws. 2010. An economic analysis of two grafted tomato production systems in the United States. HortTechnology 20:794-803.

Rosskopf, E.N., D.O. Chellemi, N. KokalisBurelle, and G.T. Church. 2005. Alternatives to methyl bromide: A Florida perspective. Online. APSnet Features. doi: 10.1094/APSnetFeature/2005-0605.

Scott, J.W., G.C. Sodomi, and J.B. Jones. 1989. Bacterial spot resistance is not associated with bacterial wilt resistance in tomato. Proc. Flo. State Hort. Soc. 101:390-392.

UNEP. 2011. The Montreal protocol on substances that deplete the ozone layer. 21 Apr. 2011. $<$ http://ozone.unep.org/new_site/en/index.php $>$.

USDA. 1976. United States standards for grades of fresh tomato. U.S. Dep. Agric., Agric. Marketing Serv. p. 1-11.

USDA-NASS. 2011. Vegetables 2010 summary. USDA, Washington D.C.

Wang, J.F., P.M. Hanson, and J.A. Barnes. 1998. Worldwide evaluation of and international set of resistance sources to bacterial wilt in tomato, p. 269-275. In: Prior, P., C. Allen, and J. Elphinstone (eds.). Bacterial wilt disease: Molecular and ecological aspects. SpringerVerlag, Berlin, Germany.

Winstead, N.N. and A. Kelman. 1952. Inoculation techniques for evaluating resistance to Pseudomonas solanacearum. Phytopathology 42:628634. 